\title{
Peningkatkan Keterampilan Membaca Intensif Dengan Model Cooperative Think Pair Sahre Pada Siswa Kelas XI Ipa 3 MAN Model Singkawang
}

\author{
Safitri $^{1)}$, Eti Sunarsih ${ }^{2)}$ \\ 1) Program Studi Pendidikan Bahasa dan Sastra Indonesia STKIP Singkawang \\ E-mail: Noaafitri17@gmail.com
}

\begin{abstract}
Abstrak. Penelitian ini dilatarbelakangi oleh rendahnya nilai membaca siswa. Hal ini dikarenakan minat membaca siswa yang masih rendah, dan siswa kurang memahami bahan bacaan yang mereka baca dengan baik. Penelitian ini difokuskan pada materi membaca intensif dengan model cooperative think pair share. Berdasarkan penjelasan tersebut , rumusan masalah yang terdapat pada penelitian adalah bagaimanakah perencanaan, bagaimanakah pelaksanaan, dan bagaimanakah hasil dari kegiatan pembelajaran membaca intensif dengan model cooperative think pair share. metode penelitian yang digunakan adalah deskriptif dengan bentuk kualitatif. penelitian ini dilaksanakan dengan 2 siklus, setiap siklus 1 kali pertemuan. prosedur penelitian dalam penelitian ini terdiri dari perencanaan, tindakan, observasi, refleksi hasil kegiatan pembelajaran. penerapan model pembelajaran cooperative think pair share dalam penelitian tindakan kelas dapat meningkatan proses pembelajaran membaca intensif. Hal ini dibuktikan dengan peningkatan kemampuan guru dalam mengelola pembelajaran, dan kegiatan dalam partisipasi siswa mengikuti proses pembelajaran. Perencanaan pembelajaran meningkat dari $74,74 \%$ pada siklus I menjadi $83,16 \%$ pada siklus II. Pelaksanaan pembelajaran meningkat dari $73,80 \%$ pada siklus I menjadi $82,1 \%$ pada siklus II. Hasil pembelajaran dengan menggunakan model pembelajaran cooperative think pair share. Peningkatan hasil belajar siswa dapat diketahui setelah membandingkan hasil pra tindakan, siklus I, dan siklus II. Nilai rata-rata yang diperoleh siswa sebelum adanya tindakan adalah 55,90\%. Pada siklus I rata-rata nilai siswa adalah 75,3 dengan persentase ketuntasan sebesar $70,60 \%$, dan pada siklus II nilai rata-rata siswa adalah 85,3 dengan persentase ketuntasan 88,23 mencapai pada peningkatan yang diharapkan. Berdasarkan penelitian ini, disarankan guru dapat menerapkan model cooperative think pair share untuk meningkatkan kemampuan membaca siswa. Guru juga harus memperhatikan model yang sesuai dengan karakteristik siswa.
\end{abstract}

Kata Kunci: keterampilan membaca, model pembelajaran cooperative think pair share.

\section{PENDAHULUAN}

Berdasarkan hasil observasi awal yang telah dilakukan peneliti menunjukkan bahwa hasil pembelajaran membaca secara intensif di kelas XI IPA MAN 3 Model Singkawang masih rendah, karena siswa berasumsi bahwa membaca adalah kegiatan yang membosankan, melelahkan dan menyita banyak waktu. Berdasarkan hasil observasi awal yang dilakukan peneliti dengan Suwarni, S.Pd., guru mata pelajaran Bahasa dan Sastra Indonesia di kelas XI IPA 3 MAN Model Singkawang, menjelaskan bahwa hasil belajar siswa dalam membaca pada kelas XI IPA 1 mencapai ketuntasan $72,72 \%$, yang artinya dari 33 siswa, hanya 24 siswa yang tuntas, kelas XI IPA $265,71 \%$, yang artinya dari 35 siswa, hanya 23 siswa yang tuntas dan di kelas XI IPA 3 $55,90 \%$ yang artinya dari 34 siswa, hanya 19 siswa yang tuntas, dari nilai kriteria ketuntasan minimum yang ditentukan sekolah yaitu 75. Berdasarkan dari permasalahan dan data tersebut diperlukan suatu perbaikan dalam pembelajaran bahasa Indonesia khususnya membaca intensif di kelas XI IPA 3 yang merupakan kelas terendah dalam pencapaian hasil belajar. Oleh karena itu penulis memilih model cooperative think pair share untuk diterapkan di kelas XI IPA 3 sebagai model pembelajaran untuk meningkatkan hasil belajar siswa pada materi membaca intensif. Penulis memilih kelas XI IPA 3 MAN Model Singkawang dikarenakan menurut sumber data yang diperoleh penulis yaitu dari guru mata pelajaran bahasa Indonesia di kelas ini hasil keterampilan menulis siswa sangat kurang dan rata-rata nilai kelas masih di bawah KKM yang seharusnya yaitu 75 , maka penulis tertarik untuk mengangkat masalah mengenai peningkatan keterampilan membaca intesnsif dengan model cooperatif think pair share pada kelas XI IPA 3 MAN Model Singkawang.

Berdasarkan latar belakang yang telah dikemukakan tersebut, maka masalah umum "Bagaimanakah model cooperative think pair share dapat meningkatkan keterampilan membaca intensif di kelas XI IPA 3 MAN Model Singkawang?". Adapun sub-sub masalah yang akan dirumuskan dalam penelitian ini adalah (1) Bagaimanakah perencanaan pembelajaran membaca intensif dengan model cooperative think pair share pada siswa kelas XI IPA 3 MAN Model Singkawang? (2) Bagaimanakah pelaksanaan pembelajaran membaca intensif dengan model cooperative think pair share pada siswa kelas XI IPA 3 MAN Model Singkawang? (3) Bagaimanakah hasil pembelajaran membaca intensif dengan model cooperative think pair share pada siswa kelas XI IPA 3 MAN Model Singkawang?. 
Tujuan penelitian ini adalah (1) Mendeskripsikan perencanaan pembelajaran untuk meningkatkan keterampilan membaca intensif dengan model cooperative think pair share pada siswa kelas XI IPA 3 MAN Model Singkawang. (2) Mendeskripsikan pelaksanaan pembelajaran untuk meningkatkan keterampilan membaca intensif dengan model cooperative think pair share pada siswa kelas XI IPA 3 MAN Model Singkawang. (3) Mendeskripsikan hasil pembelajaran untuk meningkatkan keterampilan membaca intensif dengan model cooperative think pair share pada siswa kelas XI IPA 3 MAN Model Singkawang. Hasil penelitian ini diharapkan dapat memberikan manfaat baik secara teoretis maupun praktis. Secara teoretis penelitian ini dapat menambah wawasan ilmu pengetahuan, sehingga bisa bermanfaat bagi perkembangan dunia pendidikan khususnya pada bidang pembelajaran bahasa Indonesia. Manfaat praktis yaitu bagi penulis, siswa, guru, sekolah dan lembaga STKIP.

Membaca merupakan satu di antara aspek keterampilan berbahasa. Aspek yang terdapat dalam keterampilan berbahasa dimulai dari keterampilan menyimak (listening skills), keterampilan berbicara (speaking skills), keterampilan membaca (reading skills), dan keterampilan menulis (writing skills). Membaca adalah satu dari empat kemampuan bahasa pokok, dan merupakan satu bagian atau komponen dari komunikasi lisan [9]. Kegiatan membaca adalah suatu proses untuk memperoleh pesan, melalui media kata-kata atau bahasa tulis. Membaca juga merupakan suatu kegiatan untuk memperoleh pengetahuan dan informasi [10]. Oleh karena itu, pengajaran keterampilan membaca janganlah hanya berupa latiha penguasaan kode kode-kode kebahasaan saja. Seberapa luasnya kegiatan latihan bergantung pada kepentingannya dalam memahami isi bacaan secara menyeluruh [8]. Sedangkan [5] Membaca adalah aktivitas yang kompleks dengan mengerahkan sejumlah besar tindakan yang terpisah-pisah, meliputi; orang harus menggunakan pengertian dan khayalan, mengamati, dan mengingat-ingat. Membaca intensif merupakan aktivitas yang dilakukan seseorang untuk membaca secara cermat untuk memahami suatu teks secara cepat dan akurat. Tujuan membaca intensif adalah siswa dapat memahami bacaan secara intensif, tanpa bersuara, dan tuntas. Siswa dapat memahami bacaan tertentu tanpa harus berkomat-kamit, sangat tekun, dan analisis. Kemudian siswa dapat menjawab pertanyaan bacaan sesulit apapun [7]. Menurut [10] menyatakan bahwa, "Membaca intensif atau intensive reading adalah studi saksama, telaah teliti, dan penanganan terperinci yang dilaksanakan di dalam kelas terhadap suatu tugas yang pendek kira-kira dua sampai empat halaman setiap hari. Kuesioner, latihan pola-pola kalimat, latihan kosa kata, telaah kata-kata, dikte dan diskusi umum merupakan bagian dan teknik membaca intensif. Teks-teks bacaan yang benar-benar sesuai dengan maksud ini haruslah dipilih oleh guru, baik dari segi bentuk maupun dari segi isinya". Tajuk rencana merupakan karangan berisi opini atau tanggapan yang peneliti mengenai suatu peristiwa atau masalah yang aktual. Opini disebut juga pendapat. Opini merupakan gagasan, ide atau pemikiran seseorang terhadap suatu peristiwa atau masalah. Sementara itu, fakta merupakan peristiwa yang benar-benar terjadi [4].

Model pembelajaran adalah pola atau rencana yang dapat digunakan untuk mengoperasikan kurikulum. Merancang materi pembelajaran, dan untuk membimbing belajar dalam setting kelas atau lainnya. Menurut [6] model pembelajaran ialah "pola yang digunakan sebagai pedoman dalam merencanakan pembelajaran dikelas maupun tutorial". Model dapat diartikan sebagai kerangka konseptual yang dapat digunakan sebagai pedoman dalam melakukan kegiatan[2]. Pernyataan tersebut dipertegas oleh [6] menyatakan bahwa "model pembelajaran mengacu pada pendekatan yang akan digunakan, termasuk didalamnya tujuan-tujuan pembelajaran, tahap-tahap dalam kegiatan pembelajaran, lingkungan pembelajaran, dan pengelolaan kelas". Strategi model think pair share atau berpikir berpasangan berbagi adalah merupakan jenis pembelajaran cooperative yang dirancang untuk mempengaruhi pola interaksi siswa. Menurut [3] menjelaskan bahwa model pembelajaran ini tergolong tipe cooperative sintak: guru menyajikan materi klasikal, berikan persoalan kepada siswa dan siswa bekerja kelompok dengan cara berpasangan sebangku-sebangku (think pair), presentasi kelompok (share), kuis individual, buat skor pengembangan tiap siswa, umumkan hasil kuis dan berikan reward. Secara ringkas pembelajaran tipe think pair share, yaitu : (a) thingking (berpikir), (b) Pairing (berpasangan), dan (c) sharing (berbagi). Metode pembelajaran cooperative yang memiliki prosedur ditetapkan secara eksplisit memberikan waktu lebih banyak kepada siswa untuk memikirkan secara mendalam tentang apa yang telah dijelaskan atau dialami (berpikir, menjawab, dan saling membantu satu sama lain).

\section{METODE}

Tempat atau lokasi penelitian tindakan kelas ini dilaksanakan di MAN Model Singkawang untuk mata pelajaran bahasa Indonesia kelas XI IPA 3. Penelitian ini dilaksanakan pada tanggal 3 Februari 2016 untuk siklus, sedangkan siklus II dilaksanakan pada tanggal 12 Februari 2016. Metode dalam penelitian ini menggunakan metode deskriptif. [1] mengungkapkan bahwa "Metode deskriptif merupakan metode yang dimaksudkan untuk mengumpulkan informasi atau data tentang fenomena yang diteliti, misalnya kondisi sesuatu atau kejadian, disertai dengan informasi tentang faktor penyebab sehingga muncul kejadian yang dideskripsikan secara rinci, urut, dan jujur".

Bentuk penelitian yang digunakan dalam penelitian ini adalah kualitatif. Rancangan penelitian ini menggunakan penelitian tindakan kelas. Rancangan penelitian ini menggunakan penelitian tindakan kelas, pelaksanaan penelitian tindakan kelas dalam setiap siklus mencakup empat tahap, yakni perencanaan, pelaksanaan tindakan, observasi, dan refleksi. Sumber data dalam penelitian ini adalah guru dan siswa, yaitu guru bahasa Indonesia yang bernama Suwarni, S.Pd., dan siswa kelas XI IPA 3 MAN Model Singkawang yang berjumlah 34 siswa yang terdiri dari 7 siswa laki-laki dan 27 siswa perempuan. Data dalam penelitian ini berupa data berupa data proses dan data hasil 
pembelajaran, yakni proses pembelajaran membaca intensif dan hasil belajar siswa dengan penerapan model pembelajaran cooperative think pair share.

Teknik pengumpul data merupakan suatu cara yang dilakukan peneliti untuk memperoleh data. Tanpa mengetahui teknik pengumpul data, maka peneliti tidak akan mendapatkan data yang memenuhi standar data yang di terapkan". Untuk memperoleh data dalam penelitian ini, peneliti menggunakan teknik pengumpul yaitu 1) teknik observasi langsung, 2) teknik pengukuran, 3) teknik dokumentasi. Alat pengumpul data yang digunakan dalam penelitian ini adalah lembar observasi APKG 1, APKG 2, lembar pengamatan aktivitas, lembar pengamatan sikap dan tes. Teknik analisis data yang digunakan dalam rencana penelitian ini yaitu perencanaan dinilai menggunakan APKG 1, pelaksanaan dinilai menggunakan APKG 2, dan hasil pembelajaran dianalisis dengan melakukan penilaian proses dan hasil.

\section{HASIL DAN PEMBAHASAN}

\section{Deskripsi Hasil Penelitian}

a. Deskripsi Hasil Penelitin Siklus I

1. Perencanaan Pembelajaran Membaca Intensif dengan Model Cooperative Think Pair Share Siklus 1

Pada tahap perencanaan dalam kegiatan pembelajaran membaca intensif peneliti dan kolaborator saling bekerja sama untuk menyusun kegiatan proses belajar mengajar yang akan dilaksanakan pada tanggal 3 Februari 2016 pukul 12.55-14.15 WIB. Pada tahap ini peneliti dan kolaborator merencanakan kegiatan pembelajaran.

2. Pelaksanaan Pembelajaran Membaca Intensif dengan Model Cooperative Think Pair Share Siklus I

a) Perencanaan (Planning)

Pada tahap perencanaan siklus I yang dilaksanakan pada tanggal 1 Februari 2016 peneliti dan kolaborator merencanakan pelaksanaan pembelajaran yang akan dilaksanakan ketika proses pembelajaran yaitu dengan Rencana Pelaksanaan Pembelajaran (RPP) yang meliputi merencanakan bahan ajar dan merumuskan tujuan, merencanakan pengorganisasian materi ajar, merencanakan skenario langkah-langkah pembelajaran, memilih sumber dan media, merencanakan evaluasi pembelajaran.

b) Pelaksanaan (Acting)

Pada tahap pelaksanaan siklus I dilaksanakan hari Rabu tanggal 3 Februari 2016, dengan alokasi waktu yang digunakan $2 \times 40$ menit.

c) Pengamatan (observing)

(1) Pengamatan terhadap Kemampuan Guru dalam Merencanakan Pembelajaran (APKG 1) Siklus I

Setelah peneliti melakukan pengamatan terhadap perencanaan penelitian pembelajaran dan menilai perencanaan pembelajaran yang dilakukan dari 19 aspek terdapat 4 aspek dengan kriteria sangat baik mencapai persentase 21,05\%, 8 aspek dengan kriteria baik mencapai persentase $33,68 \%, 5$ aspek dengan kriteria cukup baik mencapai persentase 15,78\%, 2 aspek dengan kriteria kurang baik mencapai persentase $4,21 \%$. Persentase yang dicapai pada perencanaan pembelajaran siklus I adalah mencapai 74,74\% (cukup).

(2) Pengamatan terhadap Kemampuan Guru dalam Melaksanakan Pembelajaran (APKG 2) Siklus I

Setelah peneliti melakukan pengamatan pembelajaran di dalam kelas dan menilai pelaksanaan pembelajaran dari 29 aspek terdapat 4 aspek dengan kriteria sangat baik dengan persentase $13,80 \%, 16$ aspek kriteria baik dengan persentase 44,14\%, 5 aspek kriteria cukup baik dengan persentase 10,34\%, 4 aspek kriteria kurang baik dengan persentase 5,51\%. Persentase yang dicapai pada pelaksanaan pembelajaran siklus I adalah mencapai $73,80 \%$ (cukup).

(3) Pengamatan terhadap Aktivitas Siswa dalam Mengikuti Pembelajaran Membaca Intensif dengan Model Cooperative Think Pair Share Siklus I

Pada pengamatan aktivitas siklus I terdapat 11 aspek yang di amati yaitu Kesiapan siswa menerima pelajaran, meyiapkan alat tulis dan buku pelajaran, perhatian siswa terhadap guru, siswa termotivasi untuk mengikuti pelajaran, Siswa membaca tajuk rencana yang dibagikan guru, siswa berpikir secara individual untuk menemukan permasalahan yang dibahas (think), Siswa membentuk kelompok secara berpasangan yang terdiri dari dua orang (berpasangan dengan teman sebangku) (pair), siswa berdiskusi dengan pasangannya untuk menyatukan pendapat mengenai permasalahan yang dibahas, tiap pasangan menyiapkan laporan hasil diskusinya, perwakilan kelompok (pasangan) menyampaikan hasil diskusi mereka di depan kelas (share), siswa lain memperhatikan temannya, dan siswa aktif dalam memberikan kesimpulan pembelajaran.

Siklus I pada kategori sangat aktif secara keseluruhan di siklus I dengan jumlah 11,77\%. Pada kategori aktif secara keseluruhan di siklus I dengan jumlah 55,89\%. Pada ketegori cukup aktif secara keseluruhan di siklus I dengan jumlah 14,70\%. Pada ketegori kurang aktif secara keseluruhan di siklus I dengan jumlah $17,64 \%$. Jadi persentase keseluruhan aktivitas siklus I adalah 64,64\% (cukup). 
(4) Pengamatan terhadap Sikap dalam Pembelajaran Membaca Intensif dengan Model Cooperative Think Pair Share Siklus I

Pada pengamatan sikap siklus I terdapat 3 aspek yaitu Aspek keaktifan, kesungguhan dan kekompakan. Hasil pengamatan sikap dengan model cooperative think pair share secara keseluruhan sebagai berikut. A) keaktifan kategori sangat baik $(14,70 \%)$, baik $(35,30 \%)$, cukup baik $(32,35 \%)$, kurang baik $(17,64 \%)$, jumlah siswa yang aktif dalam belajar $50 \%$. B) kesungguhan kategori sangat baik $(11,76 \%)$, baik $(47,05 \%)$, cukup baik $(23,53 \%)$, kurang baik $(17,64 \%)$, jumlah siswa yang sungguhsungguh dalam belajar $58,82 \%$. C) kekompakan kategori sangat baik $(14,70 \%)$, baik $(47,05 \%)$, cukup baik (20,58\%), kurang baik $(17,64 \%)$, jumlah siswa yang kompak dalam belajar $61,75 \%$. Jadi jumlah rata-rata pengamatan sikap siklus I adalah 56,75\%.

d) Refleksi (Reflecting)

(1) Refleksi terhadap Tahap Perencanaan

Refleksi terhadap perencanaan pembelajaran, sebagian besar aspek yang dinilai sudah mencapai kategori cukup baik, namun masih ada hal-hal yang perlu diperbaiki seperti berikut. (a) guru tidak menyesuaikan sumber belajar dengan karakteristik siswa (b) guru tidak menentukan media pembelajaran yang akan digunakan.

(2) Refleksi terhadap Tahap Pelaksanaan

Refleksi terhadap tahap pelaksanaan, sebagian besar aspek yang dinilai sudah mencapai kategori cukup baik namun masih ada hal-hal yang harus diperbaiki sebagai berikut. (a) Guru kurang baik dalam melakukan evaluasi dengan menanyakan ke peserta didik hambatan yang dihadapi dalam proses pembelajaran (b) guru kurang baik dalam menyimpulkan hasil pembelajaran (c) guru kurang baik dalam melakukan penilaian akhir (d) guru kurang baik dalam memberikan penguatan dan pengayaan tentang materi yang telah dipelajari.

3. Hasil Penilaian Proses Pembelajaran Membaca Intensif dengan Model Cooperative Think Pair Share Siklus I

Pada hasil proses pembelajaran membaca intensif untuk siklus I terdapat 10 siswa yang belum tuntas di antaranya 1 siswa $(2,94 \%)$ dengan rentang nilai antara $0-44,7$ siswa $(20,6 \%)$ dengan rentang nilai 45-64, 2 siswa $(5,89 \%)$ dengan rentang nilai 65-74, kemudian 24 siswa yang tuntas di antaranya 16 siswa $(47,05 \%)$ dengan rentang nilai $75-84,8$ siswa (23,52\%) dengan rentang 85-100. Agar lebih jelas dapat dilihat pada tabel 1 sebagai berikut.

\section{TABEL 1}

\begin{tabular}{cccc}
\hline Nilai & Jumlah siswa & Pencapaian & $\%$ \\
\hline $0-44$ & 1 & Tidak tuntas & $2,94 \%$ \\
\hline
\end{tabular}

\begin{tabular}{cccc}
\hline $45-64$ & 7 & Tidak tuntas & $20,6 \%$ \\
$65-74$ & 2 & Tidak tuntas & $5,89 \%$ \\
$75-84$ & 16 & Tuntas & $47,05 \%$ \\
$85-100$ & 8 & Tuntas & $23,52 \%$ \\
Jumlah & 34 & & $100 \%$ \\
\hline
\end{tabular}

b. Deskripsi Hasil Penelitian Siklus II

1) Perencanaan untuk Meningkatkan Keterampilan Membaca Intensif dengan Model Cooperative Think Pair Share Siklus II

Pada tahap perencanaan dalam kegiatan pembelajaran berpidato peneliti dan kolaborator saling bekerja sama untuk menyusun kegiatan proses belajar mengajar yang akan dilaksanakan pada tanggal 8 Februari 2016. Pada tahap ini peneliti dan kolaborator merencanakan kegiatan pembelajaran.

2) Pelaksanaan Pembelajaran Membaca Intensif dengan Model Cooperative Think Pair Share Siklus II

a) Perencanaan (Planning)

Pada tahap perencanaan siklus II yang akan dilaksanakan pada tanggal 8 Februari 2016, peneliti dan kolaborator merencanakan pelaksanaan pembelajaran yang akan dilaksanakan ketika proses pembelajaran yaitu dengan Rencana Pelaksanaan Pembelajaran (RPP) yang meliputi merencanakan bahan pembelajaran dan merumuskan tujuan, merencanakan pengorganisasian materi ajar, merencanakan skenario langkah-langkah pembelajaran, memilih sumber dan media pembelajaran, merencanakan evaluasi pembelajaran.

b) Pelaksanaan (Acting)

Pada tahap pelaksanaan siklus I dilaksanakan hari Jumat tanggal 12 Februari 2016, dengan alokasi waktu yang digunakan $2 \times 40$ menit.

c) Pengamatan (observing)

(1) Pengamatan terhadap kemampuan Guru dalam merencanakan pembelajaran (APKG 1) Siklus II

Setelah peneliti melakukan pengamatan terhadap perencanaan penelitian pembelajaran dan menilai perencanaan pembelajaran yang dilakukan dari 19 aspek terdapat 7 aspek dengan kriteria sangat baik mencapai persentase $36,84 \%, 8$ aspek dengan kriteria baik mencapai persentase $33,68 \%$, dan 4 aspek dengan kriteria cukup baik mencapai persentase 12,63\%. Persentase yang dicapai pada perencanaan pembelajaran siklus II adalah mencapai $83,16 \%$ (baik).

(2) Pengamatan terhadap Kemampuan Guru dalam Melaksanakan Pembelajaran (APKG 2) Siklus II

Setelah peneliti melakukan pengamatan pembelajaran di dalam kelas dan menilai pelaksanaan pembelajaran dari 29 aspek terdapat 8 aspek dengan kriteria sangat baik dengan persentase $27,58 \%, 16$ aspek kriteria baik dengan persentase $44,14 \%$, dan 5 aspek kriteria cukup baik dengan persentase $10,34 \%$. Persentase yang dicapai pada pelaksanaan 
pembelajaran siklus II adalah mencapai $82,1 \%$ (baik).

(3) Pengamatan terhadap Aktivitas Siswa dalam Mengikuti Pembelajaran Membaca Intensif dengan Model Cooperative Think Pair Share Siklus II

Pada pengamatan aktivitas siklus I terdapat 11 aspek yang di amati yaitu Kesiapan siswa menerima pelajaran, meyiapkan alat tulis dan buku pelajaran, perhatian siswa terhadap guru, siswa termotivasi untuk mengikuti pelajaran, Siswa membaca tajuk rencana yang dibagikan guru, siswa berpikir secara individual untuk menemukan permasalahan yang dibahas (think), Siswa membentuk kelompok secara berpasangan yang terdiri dari dua orang (berpasangan dengan teman sebangku) (pair), siswa berdiskusi dengan pasangannya untuk menyatukan pendapat mengenai permasalahan yang dibahas, tiap pasangan menyiapkan laporan hasil diskusinya, perwakilan kelompok (pasangan) menyampaikan hasil diskusi mereka di depan kelas (share), siswa lain memperhatikan temannya, dan siswa aktif dalam memberikan kesimpulan pembelajaran. Siklus II pada kategori sangat aktif secara keseluruhan di siklus II dengan jumlah 17,65\%. Pada kategori aktif secara keseluruhan di siklus II dengan jumlah 5,89\%. Pada ketegori cukup aktif secara keseluruhan di siklus II dengan jumlah $14,70 \%$. Pada ketegori kurang aktif secara keseluruhan di siklus II dengan jumlah $8,82 \%$. Jadi persentase keseluruhan aktivitas siklus II adalah 85,29\% (sangat baik).

(4) Pengamatan terhadap Sikap dalam Pembelajaran Membaca Intensif dengan Model Cooperative Think Pair Share Siklus II

Pada pengamatan sikap siklus II terdapat 3 aspek yaitu Aspek keaktifan, kesungguhan dan kekompakan. Hasil pengamatan sikap dengan model cooperative think pair share secara keseluruhan sebagai berikut. A) keaktifan kategori sangat baik $(23,53 \%)$, baik $(52,94 \%)$, cukup baik $(17,64 \%)$, kurang baik $(2,89 \%)$, jumlah siswa yang aktif dalam belajar $76,47 \%$. B) kesungguhan kategori sangat baik $(20,59 \%)$, baik $(52,94 \%)$, cukup baik $(17,64 \%)$, kurang baik $(8,83 \%)$, jumlah siswa yang sungguhsungguh dalam belajar 73,53\%. C) kekompakan kategori sangat baik $(23,53 \%)$, baik $(55,88 \%)$, cukup baik $(14,70 \%)$, kurang baik $(2,89 \%)$, jumlah siswa yang kompak dalam belajar $79,41 \%$. Jadi jumlah rata-rata pengamatan sikap siklus II adalah 76,46\%.

d) Refleksi (Reflecting)

(1) Refleksi terhadap Tahap Perencanaan
Refleksi terhadap perencanaan pembelajaran, sebagian besar aspek yang dinilai sudah mencapai kategori baik.

(2) Refleksi terhadap Tahap Pelaksanaan

Refleksi terhadap pelaksanan pembelajaran, sebagian besar aspek yang dinilai sudah mencapai kategori baik.

3) Hasil Penilaian Proses Pembelajaran Membaca Intensif dengan Model Cooperative Think Pair Share Siklus II

Pada hasil proses pembelajaran membaca intensif untuk siklus II terdapat 4 siswa yang belum tuntas di antaranya 2 siswa $(5,89 \%)$ dengan rentang nilai 45-64, 2 siswa $(5,89 \%)$ dengan rentang nilai 65-74, kemudian 30 siswa yang tuntas di antaranya 16 siswa $(47,05 \%)$ dengan rentang nilai 75-84, 14 siswa $(41,17 \%)$ dengan rentang 85-100. Agar lebih jelas dapat dilihat pada tabel 2 sebagai berikut.

TABEL 2

\begin{tabular}{|c|c|c|c|}
\hline Nilai & Jumlah siswa & Pencapaian & $\%$ \\
\hline $0-44$ & 0 & Tidak tuntas & $0 \%$ \\
\hline $45-64$ & 2 & Tidak tuntas & $5,89 \%$ \\
\hline $65-74$ & 2 & Tidak tuntas & $5,89 \%$ \\
\hline $75-84$ & 16 & Tuntas & $47,05 \%$ \\
\hline $85-100$ & 14 & Tuntas & $41,17 \%$ \\
\hline Jumlah & 34 & & $100 \%$ \\
\hline
\end{tabular}

2) Pembahasan

a. Hasil Keterampilan Guru dalam Merencanakan Proses Pembelajaran Membaca Intensif dengan Model Cooperative Think Pair Share Siklus I dan Siklus II

Berdasarkan hasil dari perencanaan guru pada siklus I mencapai persentse $74,74 \%$ dengan kategori cukup baik dan siklus II mencapai persentase $83,16 \%$ dengan kategori baik mengalami peningkatan sebesar $8,42 \%$.

b. Hasil Keterampilan Guru dalam Melaksanakan Proses Pembelajaran Membaca Intensif dengan Model Cooperative Think Pair Share Siklus I dan Siklus II

Berdasarkan hasil pelaksanaan guru dalam proses pembelajaran pada siklus I mencapai $73,80 \%$ dengan kategori cukup baik dan siklus II mencapai 82,1\% dengan kategori baik mengalami peningkatan sebesar $8,3 \%$.

c. Penilaian Aktivitas Siswa Pada Proses Pembelajaran Membaca Intensif dengan Model Cooperative Think Pair Share Siklus I dan Siklus II

Berdasarkan hasil aktivitas siswa dalam proses pembelajaran pada siklus I mencapai $67,64 \%$ dengan kategori cukup baik dan siklus II mencapai 85,29\% dengan kategori sangat baik mengalami peningkatan sebesar $17,65 \%$.

d. Penilaian Sikap Siswa Pada Proses Pembelajaran Membaca Intensif dengan Model Cooperative Think Pair Share Siklus I dan Siklus II 
Pengamatan sikap siswa dalam proses pembelajaran membaca intensif dengan model cooperative think pair share mengalami peningkatan pada siklus I dan II. Penjelasan secara rinci dapat dilihat dalam tabel 3 sebagai berikut.

TABEL 3

\begin{tabular}{ccccc}
\hline No & $\begin{array}{c}\text { Aspek yang } \\
\text { dinilai }\end{array}$ & Siklus 1 & $\begin{array}{c}\text { Siklu } \\
\text { S 2 }\end{array}$ & Peningkatan \\
\hline $\mathbf{1}$ & Keaktifan & $50 \%$ & $76,46 \%$ & $\mathbf{2 6 , 4 6 \%}$ \\
$\mathbf{2}$ & Kesungguhan & $58,82 \%$ & $73,52 \%$ & $\mathbf{1 4 , 7 \%}$ \\
$\mathbf{3}$ & Kekompakan & $6,75 \%$ & $79,4 \%$ & $\mathbf{7 2 , 6 5 \%}$ \\
$\mathbf{4}$ & Jumlah & $115,57 \%$ & $229,38 \%$ & $\mathbf{1 1 3 , 8 1 \%}$ \\
& & & $76,46 \%$ & $\mathbf{1 9 , 7 1 \%}$ \\
$\mathbf{5}$ & Rata-rata nilai & $56,75 \%$ & & \\
& sikap & & &
\end{tabular}

e. Hasil Pembelajaran Membaca Intensif dengan Model Cooperative Think Pair Share Siklus I dan Siklus II

Pada siklus I rata-rata siswa 75,3 dan pada siklus II mencapai 83,5 mengalami peningkatan sebesar $8,2 \%$. Sedangkan persentase ketuntasan siswa pada siklus I mencapai $70,60 \%$ dan pada siklus II mencapai $88,23 \%$ mengalami peningkatan sebesar $17,63 \%$.

\section{IV.SIMPULAN DAN SARAN}

\section{SIMPULAN}

Berdasarkan hasil penelitian yang dilakukan peneliti di MAN Model Singkawang keterampilan siswa dalam membaca intensif , dapat disimpulkan bahwa dalam penelitian ini mengalami peningkatan di setiap siklusnya, dibuktikan dengan beberapa hal diantaranya sebagai berikut. (1) Perencanaan pembelajaran pada siklus I mencapai $74,74 \%$ dengan kategori cukup baik dan pada siklus II mencapai $83,16 \%$ dengan kategori baik mengalami peningkatan sebesar $8,42 \%$. (2) Pelaksanaan pembelajaran pada siklus I mencapai 73,80\% dengan kategori cukup baik dan pada siklus II mencapai $82,1 \%$ dengan kategori baik mengalami peningkatan sebesar 8,3\%. (3) Hasil Pada siklus I rata-rata siswa 75,3 dan pada siklus II mencapai 83,5 mengalami peningkatan sebesar $8,2 \%$. Sedangkan persentase ketuntasan siswa pada siklus I mencapai $70,60 \%$ dan pada siklus II mencapai $88,23 \%$ mengalami peningkatan sebesar $17,63 \%$.

\section{SARAN}

Saran yang disampaikan peneliti berdasarkan hasil penelitian sebagai berikut. 1) Perencanaan pembelajaran yang dibuat hendaknya disusun sesuai dengan tuntunan kurikulum dengan memperhatikan aspek-aspek diantranya, bahan pembelajaran, strategi atau model pembelajaran, media dan sumber belajar, evaluasi sehingga tujuan pembelajaran dapat tercapai. Guru memiliki kemampuan mengajar dengan baik serta dapat menggunakan model cooperative think pair share di dalam kegiatan pembelajaran dengan tepat. 2) Guru hendaknya selalu berusaha meningkatkan pengetahuan dan kemampuannya dalam proses belajar mengajar menggunakan strategi pembelajaran yang tepat, inovatif, menarik, baik dari segi metode, pendekatan, dan rancangan, sehingga proses dan hasil pembelajaran sesuai dengan tujuan yang diharapkan. 3) Sebaiknya siswa dapat bekerja sama dalam proses pelaksanaan kegiatan pembelajaran dengan menggunakan model cooperative think pair share agar prestasi belajar mereka dapat meningkat serta melatih kemampuan mereka dalam kegiatan membaca.

\section{DAFTAR PUSTAKA}

[1] Arikunto, Suharsimi. dkk. 2014. Penelitian Tindakan Kelas. Jakarta Bumi Aksara.

[2] Dimyati dan Mudjiono. (2006). Belajar dan Pembelajaran. Jakarta: Rineka Cipta

[3] Purnama, Risma. 2014. Cooperative Learning. Pontianak: STAIN Pontianak Press.

[4] Setiyaningsih, Ika, dkk. 2013. Pegangan Guru Bahasa Indonesia. Klaten: Intan pariwara.

[5] Soedarso.2004.Speed Reading: Sistem Membaca Cepat dan Efektif Jakarta:Gramedia Pustaka Umum.

[6] Suprijono, Agus. 2009. Cooperative Learning Teori \& Aplikasi Paikem. Yogyakarta: Pustaka Pelajar.

[7] Suyatno. 2004. Teknik Pembelajaran Bahasa dan Sastra Indonesia. Surabaya: SIC.

[8] Syafi'ie. 1996. Terampil Berbahasa Indonesia. Jakarta: Balai Pustaka.

[9] Tampubolon, DP.1987. Kemampuan Membaca:Teknik Membaca Efektif dan Efisien.Bandung:Angkasa.

[10] Tarigan, Henry Guntur. 2008. Membaca Sebagai Suatu Keterampilan Berbahasa, Bandung: Bandung Angkasa. 